\title{
We Are Going up to Jerusalem! Toponyms in Two Translations of the Gospels into Balochi
}

\section{Abstract}

The history of Bible translation into Balochi goes back to the late 19th century. One century later, in 1999, a complete New Testament in Southern Balochi was published. This translation (abbreviated SBKT) was carried out in Karachi, and largely reflects the variant of Southern Balochi spoken in Karachi. There is also a more recent translation of the four Gospels into Southern Balochi (abbreviated SBCT). The text of this translation is published online. The purpose of the present article is to explore how the two translations of the four Gospels into Balochi have dealt with toponyms occurring in the Greek source text.

The toponyms are presented and discussed in alphabetical order in three different subsections (countries and provinces, towns and villages, rivers, lakes and mountains etc.) based on their names in English as found in the New Revised Standard Version from 1989.

Toponyms in the Gospels have already undergone translation rather than copying in the translation of the Gospels into the national languages of Iran and Pakistan, Persian and Urdu, which serve as models for the toponyms in the two translations studied here. SBKT basically uses the copying strategy, but with the addition of diacritics for short vowels, whereas SBCT uses the translation strategy, which involves phonological and orthographic adaptation to Balochi.

Both translations also make use of addition to make the toponyms more comprehensible to the target audience, both in comparison with the original Greek source text, and with the translations into Persian and Urdu. SBKT does so almost invariably and SBCT to a more limited extent.

Keywords: Bible Translation, Gospel texts, Balochi, toponyms, translation strategies

\section{Introduction}

The Bible is by far the most translated book in the world. According to Wycliffe Bible Translators' statistics from October 2015, the Bible has been translated in full into 554 of the world's languages, and as many as 2932 languages have a translation of at least one complete book of the altogether 66 books of the Bible. ${ }^{1}$

\footnotetext{
${ }^{1}$ http://wycliffenz.org/about/our-work/bible-translation-statistics (access: 28.05.2017).
} 
The history of Bible translation into Balochi goes back to the late $19^{\text {th }}$ century. As an example, a translation of the Gospel of Matthew into Eastern Balochi ${ }^{2}$ published in 1899 is available as a scan online. ${ }^{3}$ One century later, in 1999, a complete New Testament in Southern Balochi was published with the title Injīl Šarîf. ${ }^{4}$ This translation (here abbreviated SBKT) was carried out in Karachi, and largely reflects the variant of Southern Balochi spoken in Karachi. The alphabet used in this translation is based on the Arabic script.

There is also a more recent translation of the four Gospels into Southern Balochi. The text of this translation is published online. ${ }^{5}$ One of the translators involved in this project comes from Western (Iranian) Balochistan, more specifically from the area south of Iranshahr, and the other two translators come from Turbat in Eastern (Pakistani) Balochistan. The aim of the translators in this project (here abbreviated SBCT) is to base their translation on what has been described by $\mathrm{Ca}$ rina Jahani and Agnes Korn as "Common Balochi". ${ }^{6}$ The project uses two parallel alphabets for Balochi, one based on the Arabic script and one on the Latin script.

The purpose of the present article is to explore how the two more recent translations of the four Gospels into Balochi have dealt with toponyms occurring in the Greek source text.

Lincoln Fernandes, ${ }^{7}$ following Theo Hermans, ${ }^{8}$ divides names into conventional and loaded ones. "Conventional names are those seen as 'unmotivated' for translation, since they apparently do not carry a semantic load" and "loaded names [...] are those seen as "motivated' for translation". ${ }^{9}$ Even though the toponyms of the Bible, particularly in the Old Testament, often carry a semantic load, the tradition has been not to translate them into the target language. The two strategies that remain as reasonable choices are what Hermans ${ }^{10}$ calls copying, i.e. exactly reproducing the name of the source text in the target text, or transcription, which involves a certain degree of phonological and orthographic adaptation of the name to the target language. It is also possible to make an addition to the name, which means that "extra information is added to the original name, making it more comprehensible or perhaps more appealing to its target audience". ${ }^{11}$

\footnotetext{
${ }^{2}$ For a dialect division of Balochi, see, e.g.: C. Jahani, A. Korn, Balochi, [in:] The Iranian Languages, ed. G. Windfuhr, London-New York 2009, pp. 636-638.

${ }^{3}$ http://gospelgo.com/q/Balochi\%20Bible\%20-\%20Gospel\%20of\%20Matthew.pdf (access: 28.05.2017).

${ }^{4}$ Injīl Šarīf, Lahore 1999. http://worldbibles.org/language_detail/eng/bcc/Balochi,\%20Southern (access: 28.05.2017).

${ }^{5} \mathrm{http}: / /$ www.balochimestag.com (access: 28.05.2017).

${ }^{6}$ C. Jahani, A. Korn, op. cit., pp. 641-642. Personal communication with the translators (22.05.2017).

${ }^{7}$ L. Fernandes, Translation of Names in Children's Fantasy Literature: Bringing the Young Reader into Play, "New Voices in Translation Studies" 2006, no. 2, p. 49. Online at: http://www.researchgate.net/publication/237246131_translation_of_Names_in_Children's_Fanta sy_Literature_Bringing the Young_Reader_into_Play_i (access: 16.01.2017).

${ }^{8}$ T. Hermans, On translating Proper Names, with Reference to De Witte and Max Havelaar, [in:] Modern Dutch Studies. Essays in Honour of Professor Peter King on the Occasion of his Retirement, ed. M.J. Wintle, London 1988, pp. 1-24.
${ }^{9}$ L. Fernandes, op. cit., p. 49.
${ }^{10}$ T. Hermans, op. cit., p. 13.
${ }^{11}$ L. Fernandes, op. cit., p. 53. 


\section{Phonological Systems}

Tim Farrell ${ }^{12}$ outlines the following phonological system for the variant of Southern Balochi spoken in Karachi:

\section{Table 1. Karachi Balochi vowels}

\begin{tabular}{|l|l|}
\hline$a$ & long a \\
\hline$a$ & short a \\
\hline$i$ & long $\mathrm{i}$ \\
\hline$l$ & short $\mathrm{i}$ \\
\hline$e$ & long $\mathrm{e}$ \\
\hline$o$ & long o \\
\hline$u$ & long $\mathrm{u}$ \\
\hline$v$ & short $\mathrm{u}$ \\
\hline
\end{tabular}

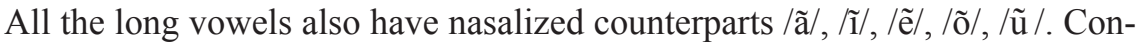
cerning diphthongs, Farrell notes that they "do occur but vary from speaker to speaker". ${ }^{13}$

Table 2. Karachi Balochi consonants

\begin{tabular}{|l|l|c|c|c|c|c|c|}
\hline & & Labial & $\begin{array}{c}\text { Dental/ } \\
\text { Alveolar }\end{array}$ & Retroflex & $\begin{array}{c}\text { Palato- } \\
\text {-alveolar/ } \\
\text { Palatal }\end{array}$ & $\begin{array}{c}\text { Velar/ } \\
\text { Uvular }\end{array}$ & Glottal \\
\hline Stops/Affricates & $\begin{array}{l}\text { (vl.) } \\
\text { (vd.) }\end{array}$ & $\begin{array}{c}p \\
b\end{array}$ & $\begin{array}{c}t \\
d\end{array}$ & $\begin{array}{c}t \\
d\end{array}$ & $\begin{array}{c}\check{c} \\
\check{J}\end{array}$ & $\begin{array}{c}k \\
g\end{array}$ & \\
\hline Fricatives & (vl.) & $f$ & $s$ & & \multicolumn{5}{c}{} & $x$ & $h$ \\
(vd.) & & $m$ & $n$ & & & & \\
\hline Nasals & & & $r$ & $r$ & & & \\
\hline Taps & & & $l$ & & & & \\
\hline Lateral & & $w$ & & & $y$ & & \\
\hline Approximants & & & & & & & \\
\hline
\end{tabular}

Concerning the fricatives $/ \mathrm{f} /, \mathrm{x} /$, and $/ \gamma /$, Farrell ${ }^{14}$ notes that $/ \mathrm{f} /$ varies freely with $/ \mathrm{p} /$, that $/ \mathrm{x} /$ is found in loanwords as a variant of $/ \mathrm{k} /$ or $/ \mathrm{h} /$, and that $/ \gamma /$ is also found in loanwords as a variant of $/ \mathrm{g} /$.

Jahani and Korn outline the following phonological system for Common Balochi: ${ }^{15}$

12 T. Farrell, Basic Balochi. An Introductory Course, "Baluchistan Monograph Series", 1, Naples 1990, pp. 11-13. Here the symbols used in Farrell's own transcription system are used.

13 Ibidem, p. 11. Here the symbols are adapted to those used in C. Jahani, A. Korn, op. cit., p. 641.

14 Ibidem, p. 12.

15 C. Jahani, A. Korn, op. cit., pp. 641-642. 
Table 3. Common Balochi vowels

\begin{tabular}{|l|c|c|c|}
\hline & front & central & back \\
\hline high & $\bar{l}, i$ & & $u, \bar{u}$ \\
\hline mid & $\bar{e}$ & & $\bar{o}$ \\
\hline low & & $a, \bar{a}$ & \\
\hline
\end{tabular}

Concerning nasals, they find that "nasal vowels are found in the vast majority of Balochi dialects. In most cases, they can be analysed as allophonic sequences of $\mathrm{V}+n[\ldots]$, but there are dialects where at least some nasal vowels seem to have acquired phonemic status." ${ }^{\prime 6}$ They also recognise two vowel + consonant combinations, ay and $a w .^{17}$

Table 4. Common Balochi consonants

\begin{tabular}{|l|l|l|l|l|l|l|}
\hline & & Labial & $\begin{array}{l}\text { Dental/ } \\
\text { Alveolar }\end{array}$ & $\begin{array}{l}\text { Palato-alveolar/ } \\
\text { Palatal }\end{array}$ & Velar & Glottal \\
\hline Stops/ Affricates & $\begin{array}{l}\text { (vl.) } \\
\text { (vd.) }\end{array}$ & $\begin{array}{l}p \\
b\end{array}$ & $\begin{array}{l}t \\
d\end{array}$ & $\begin{array}{l}\check{c} \\
\check{J}\end{array}$ & $\begin{array}{l}k \\
g\end{array}$ & \\
\hline Fricatives & $\begin{array}{l}\text { (vl.) } \\
\text { (vd.) }\end{array}$ & & $s$ & $\begin{array}{l}\check{s} \\
\check{z}\end{array}$ & & $h$ \\
\hline Nasals & & $m$ & $n$ & & & \\
\hline Tap & & & $r$ & & & \\
\hline Lateral & & & $l$ & & & \\
\hline Approximants & & $w$ & & $y$ & & \\
\hline
\end{tabular}

Jahani and Korn furthermore recognize the retroflex phonemes $/ t+/, d /$, and $/ r /$ as part of the contemporary Balochi dialects, whereas they find that the retroflex nasal /n/ "seems to have acquired phonemic status in Eastern Balochi" but probably not in other dialects. ${ }^{18}$ Concerning the fricatives $/ \mathrm{f} /, / \mathrm{x} /$, and $/ \gamma /$, they find that these phonemes are peripheral in Southern and Western Balochi, and that "the tendency to replace them by sounds found in the core of the phonemic system is strong" in Southern Balochi but weaker in Western Balochi. ${ }^{19}$

The phonology of the toponyms in the two translations will be compared to the phonological systems outlined for Karachi Balochi (Tables 1 and 2) and for Common Balochi (Tables 3 and 4). The three retroflex phonemes /ț/, /d /, and /r $/$, which are part of almost all Balochi dialects, are here regarded as part of the Com-

\footnotetext{
16 Ibidem, p. 641.

17 Ibidem.

18 Ibidem, p. 643.

19 Ibidem.
} 
mon Balochi phonological system. Since there is a strong tendency to replace the three fricatives $/ \mathrm{f} /, \mathrm{x} /$, and $/ \gamma /$ with $/ \mathrm{p} /, / \mathrm{k} /$ or $/ \mathrm{h} /$, and $/ \mathrm{g} /$, particularly in Southern Balochi, they are not regarded as part of the Common Balochi sound system. This also applies to nasalized vowels, which in many dialects of Balochi can be regarded as allophonic sequences of $\mathrm{V}+n$.

Tables 5 and 6 present the symbols used in the Latin script of SBCT for the phonemes in Common Balochi plus the three retroflex phonemes.

Table 5. Vowels in the Latin script used in SBCT

\begin{tabular}{|l|l|l|l|}
\hline & \multicolumn{1}{|c|}{ front } & central & back \\
\hline High & \multicolumn{1}{|l|}{$i, e$} & & $o, u$ \\
\hline Mid & $\dot{e}$ & & $o$ \\
\hline Low & & $a, a ́$ & \\
\hline
\end{tabular}

Table 6. Consonants in the Latin script used in SBCT

\begin{tabular}{|c|c|c|c|c|c|c|c|}
\hline & & Labial & $\begin{array}{l}\text { Dental / } \\
\text { Alveolar }\end{array}$ & $\begin{array}{l}\text { Retro- } \\
\text { flex }\end{array}$ & $\begin{array}{c}\text { Palato-alveo- } \\
\text { lar / Palatal }\end{array}$ & Velar & Glottal \\
\hline \multirow{2}{*}{ Stops / Affricates } & (vl.) & $p$ & $t$ & th & $c h$ & $k$ & \\
\hline & (vd.) & $b$ & $d$ & $d h$ & $j$ & $g$ & \\
\hline \multirow{2}{*}{ Fricatives } & (vl.) & & $s$ & & $s h$ & & $h$ \\
\hline & (vd.) & & $z$ & & $z h$ & & \\
\hline Nasals & & $m$ & $n$ & & & & \\
\hline Taps & & & $r$ & $r h$ & & & \\
\hline Lateral & & & $l$ & & & & \\
\hline Approximants & & $w$ & & & $y$ & & \\
\hline
\end{tabular}

\section{Results of the Investigation}

In this section, the toponyms being studied will be presented and discussed in alphabetical order based on their names in English as found in the New Revised Standard Version from 1989. ${ }^{20}$ The section has been divided into three sub-sections, one where countries and provinces are presented, one where towns and villages are presented, and one where other toponyms for such things as rivers, lakes, and mountains are presented. All toponyms that occur

${ }^{20}$ This version is available online at: http://www.biblestudytools.com/nrs/ (access: 16.01.2017). 
three times or more in the Greek source text will be investigated. Their spelling will be presented in the script(s) used in the actual translation. This means that Arabic script is used for items from SBKT and Latin and Arabic scripts for items from SBCT.

The toponyms are also given in Greek and in the two most likely languages of transmission, Persian and Urdu. All the terms are given in the Arabic script used for these two languages. For Persian, two forms are cited, that of the Old Persian Version and that of the New Millennium Version. ${ }^{21}$ The Old Persian Version (here abbreviated OPV) ${ }^{22}$ was published in the late $19^{\text {th }}$ century, and was therefore available at the time of the translation of both SBKT and SBCT. The New Millennium Version (here abbreviated NMV) of the New Testament ${ }^{23}$ was published in $2005^{24}$ and was therefore available only for the translation of SBCT. ${ }^{25}$ For Urdu, a version that can be downloaded from the web is used. ${ }^{26}$ Unfortunately, it has been impossible to ascertain the year of publication of this version. It is thus not entirely clear if it has been available to the translators. It is, however, assumed that the spelling of toponyms does not vary greatly between different versions of the Gospels. The version that can be accessed online was preferred to a version that would be less readily accessible, even though the year of publication of that latter version could be ascertained.

\subsection{Names of Countries and Provinces}

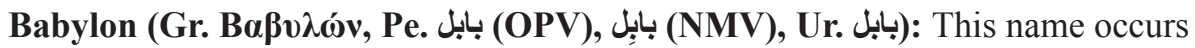
three times in the Gospel of Matthew, Chapter 1 (v. 11, 12, 17), and is rendered

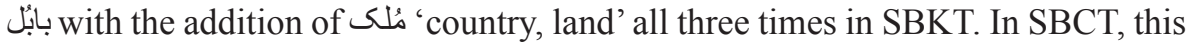
term is rendered Bábel in the Latin based script and بائبِ in the Arabic based script, but without any specifying noun.

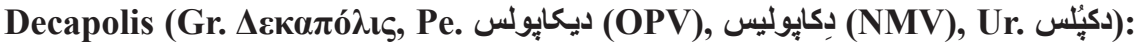
This name occurs three times in the Gospels (Matt. 4:25, Mark 5:20, 7:31) and is

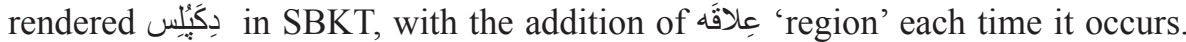
In SBCT, the rendering is Dekápulis in the Latin based script and دكايو ليس in in the Arabic based script. The word sardhagár / سردخًار 'region' is also added in the two occurrences in Mark, whereas in Matt. 4:25, where the name occurs together with a number of other toponyms, no specifying noun is added.

${ }^{21} \mathrm{http}$ //en.wikipedia.org/wiki/Bible_translations_into_Persian (access: 16.01.2017).

${ }^{22}$ Note that although the name of this translation is the "Old Persian Version", the language of this translation is not Old Persian. It is a translation into Modern New Persian, just like the New Millennium Version. The Old Persian Version is available online at:

http://www.bible.com/versions/136-pov-fas-persian-old-version (access: 16.01.2017).

23 This translation is available online at:

http://www.bible.com/versions/118-nmv-new-millenium-version (access: 16.01.2017).

${ }^{24} \mathrm{http}$ //bibleinmylanguage.com/persian-new-testament-leather-bound-by-elam (access: 16.01.2017).

25 The complete Bible was published in 2014, see:

http://en.wikipedia.org/wiki/Bible_translations_into_Persian (access: 16.01.2017).

26 http://www.christiansinpakistan.com/urdu-bible (access: 16.01.2017). 


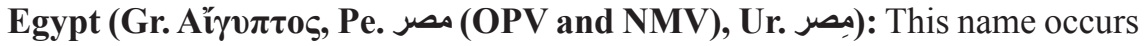
four times in the Gospel of Matthew, Chapter 2 (v. 13, 14, 15, 19). It is rendered in SBKT and Mesr / مِ in SBCT. There are altogether five occurrences in SBKT (one extra occurrence in Matt. 2:13) and four occurrences in SBCT. Neither of the translations adds any specifying noun to this name.

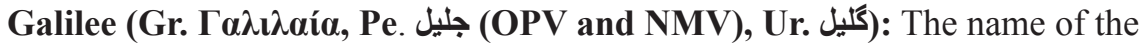
Province of Galilee occurs 53 times in the Greek text of the Gospels (see also Sea of Galilee in Section 3.3 below). The number of occurrences in Matthew is 14, in Mark it is 10, in Luke 13, and in John 16. In SBKT this name is rendered كَليل and the word صُوبَه 'province' is added on all occasions except when the name has been given in the immediate context. This happens in John 4:45 and 4:46, where the name occurs with صُوبَه in صنَوبَه 4:43 (in John 4:47 again is added), and in John 7:52, where it occurs with صُوبَّنَ 7:41.

In SBCT, the name is rendered Jalil / جَليله. The word damag / دَمَ 'province' is added three times in Matthew $(2: 22,3: 13$, and 19:1) whereas the name is left without specification on 11 occasions $(4: 12,4: 15,4: 23,4: 25,17: 22,21: 11$, $26: 32,27: 55,28: 7,28: 10,28: 16)$. There is also one occurrence of this name without further specification in the Balochi text, where it is not found in the Greek source text (14:1). In Mark, damag / دَمَ is added once (1:9) and the name is left without specification eight times $(1: 14,1: 28,1: 39,6: 21,9: 30$, 14:28, 15:41, 16:7). One time the adjective Jalili / جَليلى 'Galilean' is used instead of the name of the province (3:7). In Luke, damag / دَمخ is added twice $(1: 26,8: 26)$ and the name is left without specification 11 times $(2: 4,2: 39,3: 1$, $4: 14,4: 31,5: 17,17: 11,23: 5,23: 49,23: 55,24: 6)$. There are also three occurrences of the name without further specification $(3: 19,9: 7,23: 7)$ in places where the name is not found in the Greek source text, and one occurrence, also without further specification (23:6), where the Greek text has the adjective $\Gamma \alpha \lambda$ i $\lambda \alpha$ ĩo $\varsigma$ 'Galilean'. In John, damag / دَمَ is added once (1:43), whereas there are 15 occurrences without this addition $(2: 1,2: 11,4: 3,4: 43,4: 45,4: 46,4: 47,4: 54$, 7:1, 7:9, 7:41, 7:52 (twice), 12:21, 21:2).

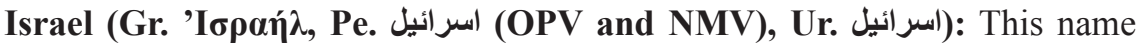
occurs 30 times in the Gospels, twelve in Matthew, two in Mark, twelve in Luke, and four in John. It is rendered إِر ائيل in SBKT and Esráil / إسراييل in SBCT. In most instances the term denotes the people of Israel, in which case the term is sometimes rendered بَنى إِر ائيل in SBKT and Bani Esráil / بنى إسر اييل in SBCT 'the House of Israel' (e.g. Matt. 2:6). Sometimes it is rendered with an adjective بَنى 'بنى in SBKT (e.g. Luke 1:80) and Bani Esráili بـنى إِسر ائيلى (Luke 1:80), or only Esráili / إسر اييلى (John 3:10) in SBCT. There are also occasions where the name denotes the people but is rendered as Esráil / إسر اييل in SBCT (e.g. Mark 12:29). Furthermore, the phrase $\beta \alpha \sigma \imath \lambda \varepsilon v$ ऽ 'I $\sigma \rho \alpha \eta ் \lambda ~ ' k i n g$ of Israel' in Matt 27:42 and Mark 15:32 is translated يَهُوديانى بادشاه 'king of the Jews' in SBKT (Esráilay bádsháh /

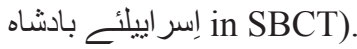

When the term clearly denotes the country, the noun sُلكى in SBKT and molk / مُلكى in SBCT meaning 'country, land' is added in Matt. 2:20 and 2:21, where also the Greek source text has the noun $\gamma \tilde{\eta}$ 'country, land'. In Matt. 10:23, SBCT has 
no added noun and SBKT has بَنى إسر ائيل 'the house of Israel'. In Luke 4:25, SBKT has the rendering بَنى إِر ائيلِ مُلكِا 'in the land of the house of Israel', whereas SBCT has the Esráilá / إسر اييلاء 'in Israel' without further specification.

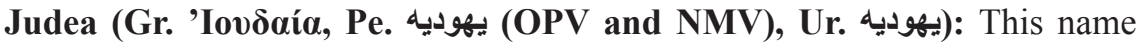
occurs 27 times in the Gospels, eight in Matthew, three in Mark, ten in Luke, and six in John. It is rendered يَهُودِيَه in SBKT and Yahudiah / يَهوديَه in SBCT. In all instances where this name is used in SBKT except Matt. 2:6 $6^{27}$ and Luke 6:17 it is accompanied by the word صُوبَه 'province'. In Luke 4:44, the name is replaced by هُلكى 'land'.

In SBCT, the word damag / دَمَّ 'province' is added four times in Matthew (2:1, $\left.2: 22,3: 5,19: 1^{28}\right)$, but on four occasions there is no addition $(2: 5,3: 1,4: 25,24: 16)$. In Mark, damag / دَمَ is added once (10:1) and is absent twice (3:8, 13:14). There is also one occurrence (1:5) of Yahudiah / يَهوديَّه with the specifying words sajjahén

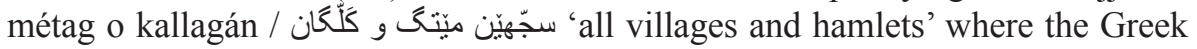

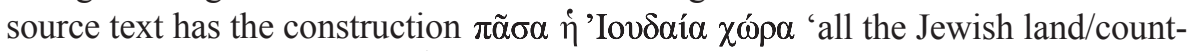
ry(side)'. In Luke, damag / دَمَ is added three times (1:5, 1:65, 23:5) and is absent seven times $(2: 4,3: 1,4: 44,5: 17,6: 17,7: 17,21: 21)$. There is also one occurrence of Yahudiah / يَهوديَه (1:39), in a longer construction with the specifying nouns kóhestáni hand o damag / كوَ هستانى هَند و دَمَ 'mountainous region', where the Greek text has the genitive form 'Iov́ $\delta \alpha$ 'of Judah'. In none of the six occurrences in the Greek text of John (4:3, 4:47, 4:54, 7:1, 7:3, 11:7) is the word damag / دَمَّ added. There is also one occurrence (3:22) of Yahudiah / يَهوديَه with the specifying words métag o kallagán / ميّتخ و كَلّكَان 'villages and hamlets' where the Greek source text

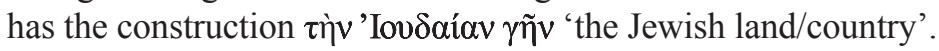

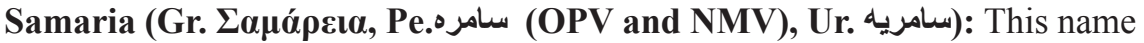
is rendered سامارِيَه in SBKT and Sámerah / سامِرَه in SBCT. The name appears four times in the Gospels (Luke 17:11, John 4:4, 4:5, 4:7) but only twice in each of the translations. In John 4:5, it is changed to the adverb 'there' in both translations

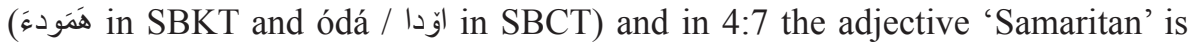
used instead of the name of the province (سامارى in SBKT and Sámeri / سامِرى ' SBCT). Both times it occurs in SBKT it is specified by the word صُوَ 'province', and in SBCT it is specified by damag / دَمَى 'province' in John 4:4, but by the noun simsar / سيمسر 'border' in Luke 17:11. This may be due to the presence of Gr. $\mu \varepsilon \sigma \circ \varsigma$ 'middle' in the original.

\subsection{Names of Towns and Villages}

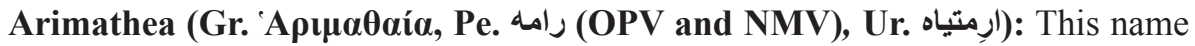
occurs four times, once in each Gospel (Matt. 27:57, Mark 15:43, Luke 23:51, John 19:38). In SBKT it is rendered آرَمَتِيَه with the addition of شَهُ 'town' in all cases. In SBCT it is rendered Arimátiá / آريماتهيا. Also here, shahr / شهر is added each time this name occurs.

\footnotetext{
${ }^{27}$ Here the Greek source text has the genitive form 'Iov́ $\delta \alpha$ 'of Judah'.

${ }^{28}$ Here the Greek source text has the word óptov 'region'.
} 


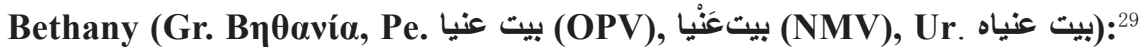
This name occurs eleven times in the Gospels (twice in Matthew, four times in Mark, twice in Luke, and three times in John) and is rendered بَيت عنِياه in SBKT and Bayt-Anyá / بئيت أنيا in SBCT. In SBKT, it is accompaned by the specifying noun مينتًََ 'village' on all eleven occasions, whereas this noun, spelled métag / ميّن in SBCT, is only found when the name occurs for the first time in each Gospel (Matt. 21:17, Mark 11:1, Luke 19:29, John 11:1), and not when it reoccurs (Matt. 26:6, Mark 11:11, 11:12, 14:3, Luke 24:50, John 11:18, 12:1).

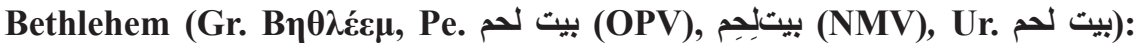
This name occurs eight times in the Gospels, five in Matt. 2 (v. 1, 5, 6, 8, 16), two in Luke 2 (v. 4, 15), and one in John 7 (v. 42). In addition, SBKT adds the name a second time in Luke 2:4 and also adds it in Luke 2:6. SBCT makes the same additions, plus a third addition in Luke 2:11. The form used in SBKT is بيت لَحَم the rendering in SBCT is Bayt-Lahem / بئيت لَّهُ

In SBKT, this name is thus found ten times, six with the word شَهز 'town' accompanying it in one way or another (Matt. 2:1, 2:5, 2:16, Luke 2:4 (twice), 2:15), two without any addition (Matt. 2:8, Luke 2:6), one with the addition of

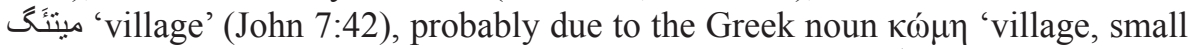
town' found in this verse, and one paraphrased as بيت لَحَم عِ نِندوكان 'inhabitants of Bethlehem' (Matt. 2:6).

In SBCT, Bayt-Lahem is found eleven times, seven with the word shahr / accompanying it in one way or another (Matt. 2:1, 2:5, 2:6, 2:11, Luke 2:4 (twice), John 7:42) and four without any addition (Matt 2:8, 2:16, Luke 2:6, 2:15).

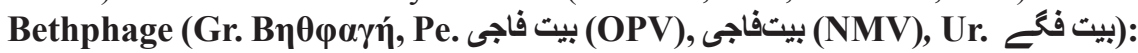
This name is found three times in the Gospels (Matt. 21:1, Mark 11:1, Luke

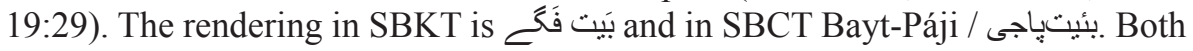
translations add the specifying noun 'village' on all three occasions, in SBKT spelled مينّنَ / مينَ / and in SBCT spelled métag.

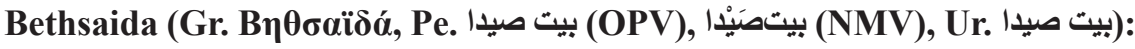
The name Bethsaida occurs seven times in the Gospels (Matt. 11:21, Mark 6:45, 8:22, Luke 9:10, 10:13, John 1:44, 12:21). In SBKT it is rendered بَيت صنيدا and is invariably accompanied by the noun شَهر 'town' (which is also found in the original text in Luke 9:10). In SBCT the rendering is Bayt-Saydá / بئيتسئيدا. In this translation, the noun shahr / شهر is present in Luke 9:10 following the Greek source text, and is also added in Mark 6:45 and John 1:44.

Cana (Gr. Kavó, Pe. قانا (OPV and NMV), Ur. قانا): This name occurs four times in the Gospel of John $(2: 1,2: 11,4: 46,21: 2)$. In SBKT it is rendered with the addition of شَهـر 'town' in all four instances. In SBCT it is rendered Káná / كانا The first introduction of Cana in SBCT (John 2:1) is as Káná námén shahréá / كانا ناميّن شهريّا 'in a town named Cana', whereas the Greek source text only has દ̇v Kavò 'in Cana'. Also in John 2:11 and 4:46 the noun shahr / شهر is added in SBCT, but in John 21:2 no specifying noun is added.

29 There are two places called Bethany in the Gospels. One is referred to in John 1:28 as a place on the east side of the river Jordan, and the second is the village on the Mount of Olives. Only the second toponym is dealt with here. 


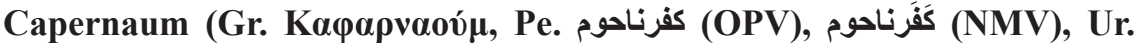
(كفرنحوم): There are 16 occurrences of this name in the Gospels (Matt. 4:13, 8:5, 11:23, 17:24, Mark 1:21, 2:1, 9:33, Luke 4:23, 4:31, 7:1, 10:15, John 2:12, 4:46, 6:17, 6:24, 6:59). The rendering in SBKT is كينَرناحُوم, and it is invariably accompanied by the noun شَهر 'town', whether or not the Greek source text has $\pi$ ó $\lambda 1 \varsigma$ 'town'. The name is added an extra time in Matt. 4:13, also here followed by شَهر. In SBCT, it is rendered Kaparnáhum / شَّرَ in Matt. 4:13, 8:5, Mark 1:21, John 2:12, 4:46. In Luke 4:31, where the noun $\pi$ ó $\lambda 1 \varsigma$ 'town' is also found in the Greek source text, the construction is Issá Ka-

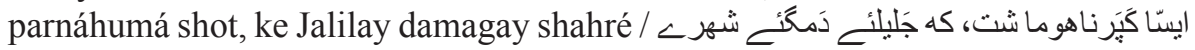
'Jesus went to Capernaum, which is a town in the Province of Galilee'. The name is also added an extra time in Matt 4:13 and in John 4:47. In these two instances

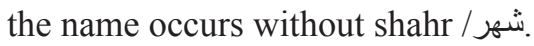

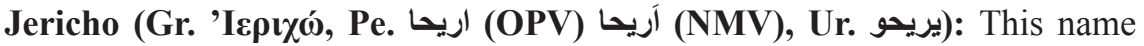
is found six times in the Gospels (Matt. 20:29, Mark 10:46 (twice), Luke 10:30, 18:35, 19:1). It is rendered بَريحُ in SBKT and Arihá / آريها in SBCT. In SBKT, it is

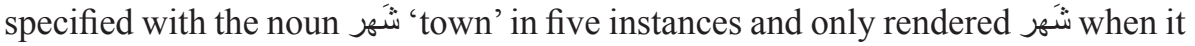
occurs a second time in Mark 10:46. In SBCT it is specified with shahr/ شهر four times (Matt. 20:29, Mark 10:46, Luke 10:30, 18:35) and left unspecified twice (Mark 10:46 (second occurrence), Luke 19:1).

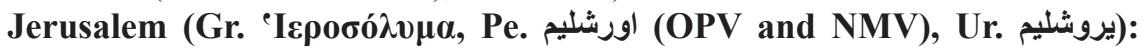
The name Jerusalem occurs 64 times in the Gospels, 13 in Matthew, 9 in Mark, 31 in Luke, and 11 in John. There are also two occurrences of the adjective

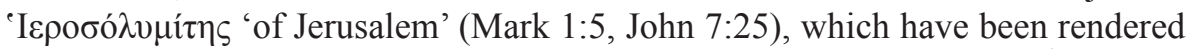

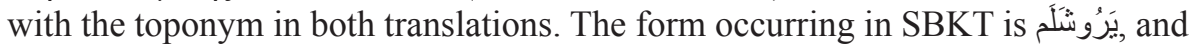
the form in SBCT is Urshalim / اورْنَلَيم.

In SBKT, the name normally occurs with the noun شَهر 'town'. However, when the name with شَهر has been mentioned in the immediate context, شَهر is sometimes omitted (e.g. Matt. 20:18 [mentioned in 20:17], Luke 2:43, 2:45 [mentioned in 2:41], John 4:21 [mentioned in 4:20]), but in John 5:1 and 5:2 شَهر is present in two consecutive verses. The noun شَهر is also occasionally omitted without any mention in the immediate context (e.g. Luke 6:17, John 1:19). It is likewise omitted when the noun نِندوكان 'inhabitants' is added (e.g. Luke 13:34). On one

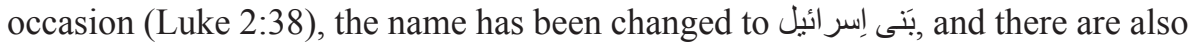
two additions (Luke 24:50 and John 10:23) and one omission (John 10:22) of Jerusalem, compared to the Greek source text.

In SBCT, shahr / شهر is added in Matt. 2:1, Mark 1:5 (adjective in Gr.), Luke 2:25, and John 1:19, which are the first occurrences in three of the Gospels (Matthew, Mark, John) and the second occurrence in Luke, the first being Luke 2:22. The name Jerusalem has also been added in Matt. 27:53, Luke 2:42, 19:41, 23:19 (here with shahr / شهر where the Greek source text has only $\pi$ ó $\lambda 1 \varsigma$ 'town' and not the name 'Ispoбó $\lambda v \mu \alpha$ 'Jerusalem'), as well as in John 7:10 (here without shahr / شُهر).

Nazareth (Gr. Naלapá, Pe. ناصره (OPV and NMV), Ur. ناصرت): There are eleven occurrences of the name Nazareth in the Gospels (Matt. 2:23, 4:13, 21:11, 
Mark 1:9, Luke 1:26, 2:4, 2:39, 2:51, 4:16, John 1:45, 1:46). In SBKT, this name is spelled ناصرَت ' شَهر 'town' in all instances except John 1:46, regardless of whether or not $\pi$ ó $\lambda 1 \varsigma$ 'town' is present in the Greek source text. In SBCT the name is rendered Náserah / ناسِرَه and is accompanied by the noun shahr / شهر in Matt 2:23 (here also in Gr.), 4:13, 21:11, Mark 1:9, Luke 1:26 (here also in Gr.), 2:4 (here also in Gr.), 2:39 (here also in Gr.). There is no specifying noun in Luke 2:51, 4:16, John 1:46. In John 1:45 it is replaced by the adjective Náseri / ناسِرى 'Nazarene'.

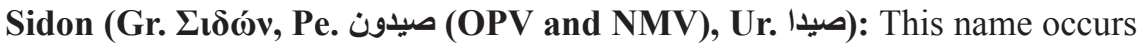
eight times in the Gospels, always together with Tyre (see below) (Matt. 11:21, 11:22, 15:21, Mark 3:8, 7:31, Luke 6:17, 10:13, 10:14) and it is rendered صنيدا in SBKT. The noun شَهر 'town' accompanies the name one way or another on all occasions. In SBCT the rendering is Saydun / سئيدون, and the noun shahr / شهر is added in Matt. 11:21 and Luke 10:13. The adjective $\Sigma 1 \delta \omega$ vios 'of Sidon' is also found in the Greek source text of Luke 4:26. This adjective is rendered with the

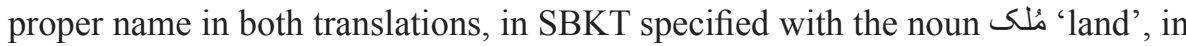
SBCT in the construction Saydunay shahr Sarapah / سئيدونتُ شهر سَرَبَه 'Zarephath, the town of Sidon'.

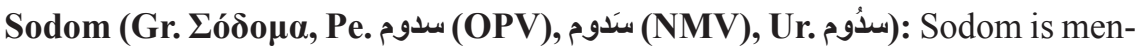
tioned five times in the Gospels (Matt. 10:15, 11:23, 11:24, Luke 10:12, 17:29). The rendering in SBKT is سندُوم and in SBCT Sodum / سُدوم: In SBKT, the noun

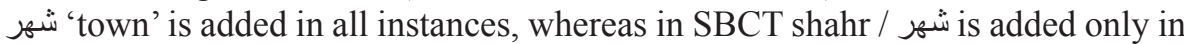
Matt. 11:23 and Luke 17:29. SBCT also adds the name once more in Luke 17:29, this time without shahr / شور

Tyre (Gr. Tópos, Pe. صور (OPV and NMV), Ur. صور): This name occurs nine times in the Gospels, in all but one instance together with Sidon (see above) (Matt. 11:21, 11:22, 15:21, Mark 3:8, 7:24, 7:31, Luke 6:17, 10:13, 10:14). It is rendered صُور in SBKT, where the noun شَهر 'town' always accompanies the name one way or another. In SBCT the rendering is Sur سور / شهر / and the noun shahr is added only in Matt. 11:21 and Luke 10:13.

\subsection{Other Toponyms}

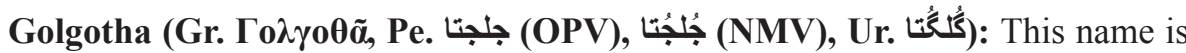
mentioned three times in the Gospels (Matt. 27:33, Mark 15:22, John 19:17), and in all three instances it is explained as Kpavíov Tó $\pi$ os 'place of skull'. In SBKT,

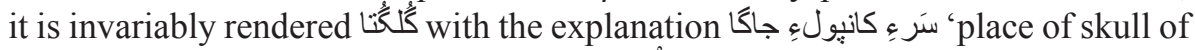

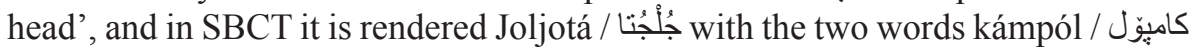
‘skull' and jágah / جاكَه 'place' also occurring in the explanation.

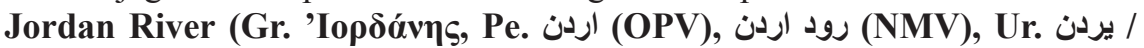
(دريائــ يردن): This name occurs 15 times in the Gospels (Matt. 3:5, 3:6, 3:13, 4:15, 4:25, 19:1, Mark 1:5, 1:9, 3:8, 10:1, Luke 3:3, 4:1, John 1:28, 3:26, 10:40) and in SBKT, it is everywhere rendered أردُن دَريا:Jordan Sea'. In SBCT, the rendering is

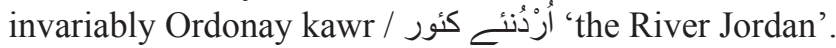

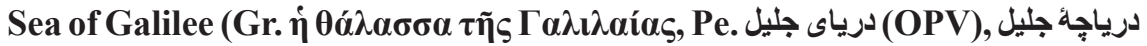
(NMV), Ur. كليل كى جهيل): This name is found five times in the Gospels (Matt. 
4:18, 15:29, Mark 1:16, 7:31, John 6:1). In SBKT, كَليَل دَريا 'Galilee Sea' is found in all five instances, and also in Matt. 4:13 and Mark 5:1. The name is rendered Jalilay mazangwarm / جَليلئح مَزَنَكَورم 'big-lake of Galilee' in SBCT, where it is also added in the same verses as in SBKT. The Sea of Galilee is also mentioned in the Greek source text as only $\dot{\eta} \theta \alpha \dot{\lambda} \alpha \sigma \sigma \alpha$ 'the sea' (e.g. in Matt. 13:1), in which case the rendering in SBKT is دَريا 'sea', and in SBCT مَزَنَكَّرم 'big-lake'.

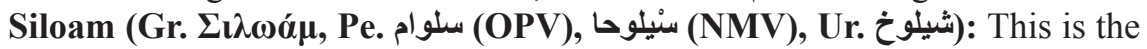
name of a water supply system in Jerusalem that is mentioned three times in the Gospels. In Luke 13:4 a tower at Siloam is mentioned, which had collapsed

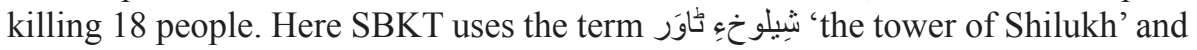
SBCT has Siluháay borj / سيلو هائح بُرج ج the tower of Siluha' corresponding to the

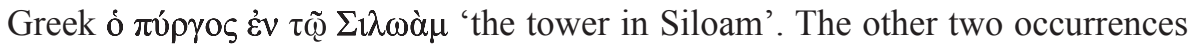
are in John 9 (v. 7 and 11), where the reference is to the water at Siloam, but without any specifying word in the Greek source text. In both verses SBKT has the rendering شَيلوخ خَوض 'the Shilukh pool' and SBCT has the rendering Siluháay taláwag / سيلو هائح تَلاوخت 'the pool of Siluha'.

\section{Summary}

There are a number of interesting issues related to the toponyms in the two translations of the Gospels into Balochi studied here. One concerns whether it is possible to determine the source language for the toponyms in the two translations, and another concerns the extent to which the toponyms follow the phonological pattern of the variant of Balochi (Karachi Balochi and Common Balochi) that the translation is based on. A third question is whether full vocalization of the names is given in the Arabic script in order to facilitate the reading of the names. ${ }^{30}$ A fourth point concerns to what extent the translation provides extra information about the toponyms in order to help the reader, for whom these names may be unknown.

On the question of the source language, it is quite clear from the data presented that the SBKT translation, with a few exceptions, follows the Urdu rendering of toponyms, whereas the SBCT translation mainly follows the Persian rendering. When the OPV and NMV diverge, it is the rendering in NMV that serves as a model. Thus, the actual source language of the Gospels, Greek, does not serve as the source language for the toponyms.

The phonological pattern of Common Balochi is exactly reflected in SBCT. Furthermore, the orthography of SBCT only has one rendering of each phoneme, even when Persian and Urdu have different letters for one phoneme (e.g. w and ص for/s/). It is somewhat difficult to determine whether spellings in SBKT such as بِيلوخ with the phoneme /x/ and بيت فَحَح with the phoneme /f/ are meant to reflect the Balochi pronunciation of these toponyms, or if they are copied from Urdu. The spelling قانا also contains the phoneme /q/, which is not present in Ka-

30 This study does not discuss at length other details of the orthographies chosen in the two different translations. 
rachi Balochi, and the spellings of, for example, صَيدا aيت عنباه , بئور contain letters that do not correspond to any phoneme in Balochi or Urdu. It is thus clear that SBKT preserves the Arabic-Persian-Urdu spelling of proper names rather than spelling them in accordance with the phonology of Balochi, and specifically that of Karachi Balochi. It is therefore likely that شِيَلو aيت فَحَ and also copies from Urdu.

The Arabic script employed in the two translations SBKT and SBCT follows the convention of not representing short vowels with letters (contrary to Kurdish in Arabic script, for example, which inserts letters for short vowels). Both translations, however, add diacritics that represent the short vowels in toponyms in order to guide the reader in pronouncing them correctly.

As for extra information about the toponyms, the SBKT translation supplies such information richly, and SBCT more sparingly. When a name is expected to be well known, such as Babylon (in SBCT) and Egypt (in SBKT and SBCT), no extra information is added to the name, but with all other names additional information is given. In SBCT this is mainly done on the first occurrence(s) in each Gospel, and in SBKT basically throughout the text, if the name has not been mentioned in the immediate context.

\section{Conclusions}

Toponyms encountered in the Greek source text of the Gospels have already undergone translation rather than copying in the translation of the Gospels into the national languages Urdu and Persian, which serve as models for the toponyms in the two translations studied here. It is also clear that the Arabic phonological system, which lacks the phoneme $/ \mathrm{g} /$, has interfered with the rendering of names

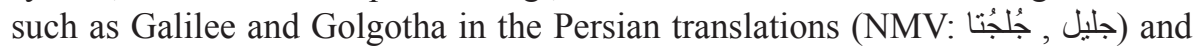
also with the spelling of toponyms such as صيدون ,صبدا / صيدون , بيت عنياه / بيت عنيا in both the Persian and the Urdu translation.

If the national languages, Urdu for SBKT and Persian for SBCT (as is evident from the renderings of the toponyms in the target text), are regarded as the source texts, SBKT basically uses the copying strategy, but with the addition of diacritics for short vowels, whereas SBCT uses the translation strategy, which involves phonological and orthographic adaptation to Balochi.

It is also clear that both translations make use of addition to make the toponyms more comprehensible to the target audience, both in comparison with the original Greek source text, and with the Urdu and Persian translations. SBKT does so almost invariably and SBCT to a more limited extent.

\section{List of Abbreviations}

Gr. $\quad-$ New Testament Greek

Matt. - The Gospel according to Matthew

NMV - New Millennium Version

OPV - Old Persian Version 
Pe. - Persian

SBCT - Southern Balochi Common Translation

SBKT - Southern Balochi Karachi Translation

Ur. - Urdu

v. - verse

vd. - voiced

vl. - voiceless

\section{Bibliography}

Farrell T., Basic Balochi. An Introductory Course, "Baluchistan Monograph Series", 1, Naples 1990.

Fernandes L., Translation of Names in Children's Fantasy Literature: Bringing the Young Reader into Play, "New Voices in Translation Studies" 2006, no. 2, pp. 44-57. Online: http://www.researchgate.net/publication/237246131_translation of_Names_in_Children's_Fantasy_Literature_Bringing_the_Young_Reader_ into_Play_i (access: 16.01.2017).

Hermans T., On Translating Proper Names, with Reference to De Witte and Max Havelaar, [in:] Modern Dutch Studies. Essays in Honour of Professor Peter King on the Occasion of his Retirement, ed. M.J. Wintle, London 1988, pp. 1-24.

Injīl Šarīf, Lahore 1999.

Jahani C., Korn A., Balochi, [in:] The Iranian Languages, ed. G. Windfuhr, LondonNew York 2009, pp. 634-692.

\section{On-line Sources}

http://bibleinmylanguage.com/persian-new-testament-leather-bound-by-elam (access: 16.01.2017).

http://en.wikipedia.org/wiki/Bible translations into_Persian (access: 16.01.2017). http://gospelgo.com/q/Balochi\%20Bible\%20-\%20Gospel\%20of\%20Matthew.pdf (access: 28.05.2017).

http://worldbibles.org/language_detail/eng/bcc/Balochi,\%20Southern (access: 28.05.2017). http://www.balochimestag.com (access: 28.05.2017).

http://www.bible.com/versions/118-nmv-new-millenium-version (access: 16.01.2017). http://www.bible.com/versions/136-pov-fas-persian-old-version (access: 16.01.2017). http://www.biblestudytools.com/nrs/ (access: 16.01.2017). http://www.christiansinpakistan.com/urdu-bible (access: 16.01.2017). http://wycliffenz.org/about/our-work/bible-translation-statistics (access: 28.05.2017). 